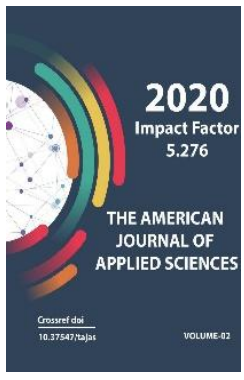

Copyright: Original content from this work may be used under the terms of the creative commons attributes 4.0 licence.

\section{High Hearing Memory Of Schoolchildren And Students And Factors Affecting It}

\author{
M. M. Mamajanov
}

Ph.D, Senior Lecturer Of The Department Of Physiology And Fundamentals Of Valeology, Namangan State University

B. B. Turayev

Student Of Namangan State University, Uzbekistan

\title{
ABSTRACT
}

Non-regular mental and physical activity of schoolchildren and students, excessive use of mobile phones, harmful habits (smoking and snuff), iodine deficiency, poor diet, lack of sleep are the main reasons for memory loss decrease is observed. In our experiments, long-term memory volume was up to $37 \%$ and short-term memory volume was up to $51 \%$ in 6 th grade students (13-year-olds); In 8 th grade students (15-year-olds), long-term memory was up to $83 \%$ and short-term memory was up to $61 \%$; In 10th grade students (17-year-olds), long-term memory volume was up to $83 \%$ and short-term memory volume was up to $57 \%$; In first-year students (19-year-olds), we found that long-term memory decreased by $68 \%$ and short-term memory by $49 \%$. Decreased memory, in turn, has a negative impact on the mastery performance of pupils and students.

\section{KEYWORDS}

Memory decline, mastery indicators, long-term memory, short-term memory, iodine deficiency, memory

exercise, memory

performance.

\section{INTRODUCTION}

Actuality of the topic: The future of our country, which is developing in all areas, depends on how educated and intelligent students and young people are. In order for young people to achieve high results, to find their place in the future and become competitive professionals, their intellectual abilities, especially their memory, must be well developed. Strong memory is the basis of 
learning, learning foreign languages and acquiring a profession.

It is known that under the influence of external and internal environment, excitation occurs in the central nervous system, especially in the nerve cells of the cerebral cortex, in the higher nerve centers. This excitation disappears after a certain time, but its trace remains, and the trace of the effect left on these nerve centers that is called memory. Hence, memory is the recollection of various events, experiences, and accomplishments over a period of time [2; 93].

Memory is short and long lasting. Short-term memory. In medical practice, a person loses the ability to remember the brain during certain illnesses, even though he or she remembers things well before. This concussion is observed in people with severe alcoholism. Psychologists have also shown that people with severe mental illness cannot remember the events that preceded it. They also remember well the events they remembered before. With this in mind, E. Hebb (1949) divided memory into short-term and long-term memory. Short-term memory impairment is associated with a strong impact on the brain after an event. Short-term memory roughly corresponds to primary memory and does not last long. Some data from short-term memory can be transferred to long-term memory, and the data transferred to this system can last for months, sometimes years, or even a lifetime. There is a huge difference between remembering what happened now and remembering memories of the distant past. The first is remembered quickly, while the second is more difficult to remember and takes time. The amount of short-term memory is very small, making up several storage units. This is why it is called short-term memory. Secondary and tertiary memories correspond to long-term memory [3; 345].
Traces of exposure in long-term memory are stored in brain cells for long periods of time, some for a lifetime. In addition, the more each effect (information, event) is repeated, the longer it will be remembered. However, everyone's memory of different events will be different depending on the characteristics of the nervous system. For example, a compassionate person remembers the grief of others for a long time, cares about them, seeks help [2; 94].

The amount of memory a person has depends on many factors, such as heredity of memory, healthy lifestyle, normal sleep, complete nutrition, adequate iodine and vitamins in food, correct from mobile phones use, abstinence from harmful habits, and memory exercises.

A properly structured agenda is important for students 'health and harmonious development. The same thing helps in the recovery of the body's physical and psychological strength during chronic fatigue, resulting in the strengthening of intellectual qualities such as concentration, memory [4; 73-74].

Deterioration of health due to electromagnetic radiation occurs in mobile phone users. They are particularly prone to memory, attention deficit, and sleep disturbances [5; 175-176].

Radiation from a cellular device affects substances in the blood-brain barrier that allow blood to enter brain tissue and damage cells. The risk of developing cancer is high [6; 50-53].

Students who use a cell phone will also be deprived of simple memory exercises. For example, they cannot memorize the phone numbers of acquaintances and even their loved ones, or perform simple mathematical operations such as addition, subtraction, and multiplication without a telephone. 
A person receives 3-5 grams of iodine throughout his life. A person needs 200 micrograms (one millionth of 1 gram) a day. If iodine deficiency occurs in adults, it can lead to goiter, and in children to mental retardation, growth retardation, neurological and other diseases. If there is a lack of iodine in the body, the average rate of mental development is $15-20 \%$ lower [7; 210]. lodine deficiency in food negatively affects the mental development of children and adolescents and leads to memory loss [8; 4348]. lodine deficiency disease impairs physical, mental, and sexual development in children and adolescents. In this disease, the level of thyroid hormones is reduced because thyroid hormones contain iodine atoms [9; 103]. Studies have shown that iodine deficiency in children reduces attention, brain perception, memory, and the process of analysis-synthesis of the brain by $15-44 \%$ [10; 358-363].

It is known that the younger the child, the more anatomically and especially physiologically it differs from the adult organism. Accordingly, tobacco has a stronger negative effect on young people than on adults. Because the young organism is not yet fully developed and is very sensitive to toxins. If a child starts smoking, especially during adolescence, he or she will experience anemia, the oxygen supply to brain tissue will deteriorate, memory will decline, and he or she will become irritable. Adolescents who smoke do not do well in school, fall behind in sports, and often become ill. When examining the effects of tobacco on children's ability to work, it was found that if non-smoking students' ability to work is considered to be $100 \%$, this figure is $92 \%$ for low-smokers and $77 \%$ for high-smokers [7; 190].

Sleep is a complex, multi-stage, and irreversible human need. According to experts, a third of a person's life is spent asleep. During sleep, the activity of the central nervous system, especially the neocortex, decreases, muscle tone, sensitivity to receptors decreases. Unconditioned reflexes are weakened, while conditioned reflexes are inhibited. As a result of sleep disorders, various somatic and vegetative changes occur in the body. As a result, human memory decreases [11; 439].

The biological significance of physical education is that properly structured physical education changes the type of higher nervous activity, improves neural processes, increases their strength, balance and mobility [11; 449].

It is known that physical culture is a very important tool of education, because it provides practical assistance to the all-round development of a person, develops his mental, physical, spiritual and aesthetic abilities. Physical education should cover all segments of the population, from children to the elderly. Therefore, physical training greatly contributes to education and health, mainly through the development of motor activity of the human body, prolongs life [11; 235].

Exercise increases the release of the hormones norepinephrine and dopamine in the body. These hormones, in turn, are neurotransmitters that stimulate parts of the hippocampus that respond to short- and longterm memory [13].

By the age of 10-11, children's memory capacity increases, almost to the level of adults. By adolescence, memory performance decreases significantly as a result of deterioration in nerve cell function [14]. Studies by Russian psychiatrist S. S. Korsakov have shown that memory improves by the age of 20-25 years, then remains unchanged by the age of 40-45 years, and then steadily decreases [15].

\section{MATERIALS AND METHODS}

To determine the amount of long-term auditory memory, students were read 10 abstract concepts. They wrote their marks on a white sheet of paper to remember the 
concepts they had heard (the use of letters, words, and numbers was prohibited). Forty minutes later, students were asked to write the concepts next to the signs.

To determine the amount of short-term auditory memory, we used an 8-row table consisting of single-digit numbers. The number of digits in the first row of the table increases by 3 , in the next rows by one, resulting in 8 rows of 10 digits. Healthy people should remember 7 numbers in the 5 th row in the norm $[1 ; 114-116]$.

\section{RESULTS AND THEIR ANALYSIS}

The results obtained for determining longterm auditory memory volume are presented in Tables 1-2-3-4. Our research was conducted in 6th, 8th, 10th grade students of 13th and 31st schools in Namangan (Uzbekistan) (100 students in each class) and Namangan State University (Uzbekistan) Faculty of Pedagogy, conducted in primary education and sports educational work students (100 people).

Table 1

Long-term auditory memory capacity of 6 th grade students

\begin{tabular}{|c|c|c|c|c|c|c|c|c|}
\hline \multirow[t]{2}{*}{ Number of auditors } & \multicolumn{8}{|c|}{ Number of correct answers } \\
\hline & 3 & 4 & 5 & 6 & 7 & 8 & 9 & 10 \\
\hline 100 & 23 & 14 & 15 & 9 & 12 & 8 & 13 & 6 \\
\hline $100 \%$ & $23 \%$ & $14 \%$ & $15 \%$ & $9 \%$ & $12 \%$ & $8 \%$ & $13 \%$ & $6 \%$ \\
\hline Satisfactory /Unsatisfactory & \multicolumn{2}{|c|}{$37 \%$} & \multicolumn{6}{|c|}{$63 \%$} \\
\hline
\end{tabular}

Table 2

Long-term auditory memory capacity of 8th grade students

\begin{tabular}{|c|c|c|c|c|c|c|c|c|}
\hline \multirow{2}{*}{$\begin{array}{c}\text { Number of } \\
\text { auditors i }\end{array}$} & \multicolumn{7}{|c|}{ Number of correct answers } \\
\cline { 2 - 9 } & 3 & 4 & 5 & 6 & 7 & 8 & 9 & 10 \\
\hline 100 & 34 & 5 & 15 & 18 & 11 & 9 & 5 & 3 \\
\hline $100 \%$ & $34 \%$ & $5 \%$ & $15 \%$ & $18 \%$ & $11 \%$ & $9 \%$ & $5 \%$ & $3 \%$ \\
\hline
\end{tabular}


Table 3

Long-term auditory memory capacity of 10th grade students

\begin{tabular}{|c|c|c|c|c|c|c|c|c|}
\hline \multirow{2}{*}{ Number of auditors } & \multicolumn{8}{|c|}{ Number of correct answers } \\
\cline { 2 - 9 } & 3 & 4 & 5 & 6 & 7 & 8 & 9 & 10 \\
\hline $\mathbf{1 0 0}$ & 33 & 7 & 26 & 9 & 8 & 8 & 4 & 5 \\
\hline $\mathbf{1 0 0} \%$ & $33 \%$ & $7 \%$ & $26 \%$ & $9 \%$ & $8 \%$ & $8 \%$ & $4 \%$ & $5 \%$ \\
\hline Satisfactory /Unsatisfactory & \multicolumn{1}{|c|}{$83 \%$} & & \multicolumn{3}{|c|}{$17 \%$} \\
\hline
\end{tabular}

Table 4

Long-term auditory memory capacity of 1st year students

\begin{tabular}{|c|c|c|c|c|c|c|c|c|}
\hline \multirow[t]{2}{*}{ Number of auditors } & \multicolumn{8}{|c|}{ Number of correct answers } \\
\hline & 3 & 4 & 5 & 6 & 7 & 8 & 9 & 10 \\
\hline 100 & 2 & 5 & 26 & 18 & 17 & 28 & 4 & - \\
\hline $100 \%$ & $2 \%$ & $5 \%$ & $26 \%$ & $18 \%$ & $19 \%$ & $28 \%$ & $4 \%$ & 0 \\
\hline $\begin{array}{l}\text { Satisfactory } \\
\text { /Unsatisfactory }\end{array}$ & \multicolumn{5}{|c|}{$68 \%$} & \multicolumn{3}{|c|}{$32 \%$} \\
\hline
\end{tabular}

In healthy individuals, long-term auditory memory is considered satisfactory if the volume is higher than 7, and unsatisfactory if the result is lower. The tables show that those with scores above 7 were 27 students (27\%) out of 100 in 6 th grade, 17 students (17\%) in 8 th grade, and 17 students (17\%) in 10th grade. Among first-year students, 32 students (32\%). 
It can be seen that long-term memory volume decreased to $37 \%$ in 6 th grade students, to $83 \%$

in 8 th grade students, to $83 \%$ in 10 th grade students, and to $68 \%$ in 1 st year students.

In our subsequent research, we determined the amount of short-term auditory memory of the same pupils and students. We presented the results obtained in Tables 5-6-7-8. We know that in the norm, people's short-term auditory memory size is 7 , which means they have to remember the 7 numbers in the 5 th row. In our study, students who showed normal and higher results were 49 in the 6 th grade (49\%), 39 in the 8 th grade (39\%), 43 in the 10th grade (43\%), and 51 in the 1st grade ( $51 \%)$. It can be seen that the amount of shortterm auditory memory decreased to $51 \%$ in 6th grade, $61 \%$ in 8 th grade, $57 \%$ in 10 th grade, and $49 \%$ in 1 st year students (Tables 5-6-7-8).

It is noteworthy that the amount of shortterm auditory memory was lower in 8th and 10th grade students than in 6th grade students. This is normal and is associated with the processes of transition to puberty.

Table 5

Short-term auditory memory capacity of 6th grade students

\begin{tabular}{|c|c|c|c|c|c|c|c|c|}
\hline \multirow{2}{*}{ Number of auditors } & \multicolumn{8}{|c|}{ Number of correct answers } \\
\cline { 2 - 9 } & 3 & 4 & 5 & 6 & 7 & 8 & 9 & 10 \\
\hline 100 & 2 & 5 & 26 & 18 & 17 & 28 & 4 & - \\
\hline $100 \%$ & $2 \%$ & $5 \%$ & $26 \%$ & $18 \%$ & $19 \%$ & $28 \%$ & $4 \%$ & 0 \\
\hline Satisfactory /Unsatisfactory & \multicolumn{3}{|c|}{$68 \%$} & \multicolumn{3}{|c|}{$32 \%$} \\
\hline
\end{tabular}

Table 6

Short-term auditory memory capacity of 8 th grade students

\begin{tabular}{|c|c|c|c|c|c|c|c|c|}
\hline Number of auditors & \multicolumn{7}{|c|}{ Number of correct answers } \\
\cline { 2 - 9 } & 3 & 4 & 5 & 6 & 7 & 8 & 9 & 10 \\
\hline 100 & 2 & 5 & 26 & 18 & 17 & 28 & 4 & - \\
\hline
\end{tabular}




\begin{tabular}{|c|c|c|c|c|c|c|c|c|}
\hline $100 \%$ & $2 \%$ & $5 \%$ & $26 \%$ & $18 \%$ & $19 \%$ & $28 \%$ & $4 \%$ & 0 \\
\hline Satisfactory /Unsatisfactory & \multicolumn{8}{|c|}{$68 \%$} \\
\hline
\end{tabular}

Table 7

Short-term auditory memory capacity of 10th grade students

\begin{tabular}{|c|c|c|c|c|c|c|}
\hline \multirow{2}{*}{\begin{tabular}{|c|} 
Number of auditors \\
\cline { 2 - 7 }
\end{tabular}} & 3 & 4 & 5 & 6 & 7 & 8 \\
\hline 100 & 32 & 25 & 20 & 11 & 5 & 7 \\
\hline $\mathbf{1 0 0}$ & $32 \%$ & $25 \%$ & $20 \%$ & $11 \%$ & $5 \%$ & $7 \%$ \\
\hline $\begin{array}{c}\text { Satisfactory } \\
\text { Unsatisfactory }\end{array}$ & \multicolumn{2}{|c|}{$57 \%$} & & & & \\
\end{tabular}

Table 8

The amount of short-term auditory memory of 1st year students

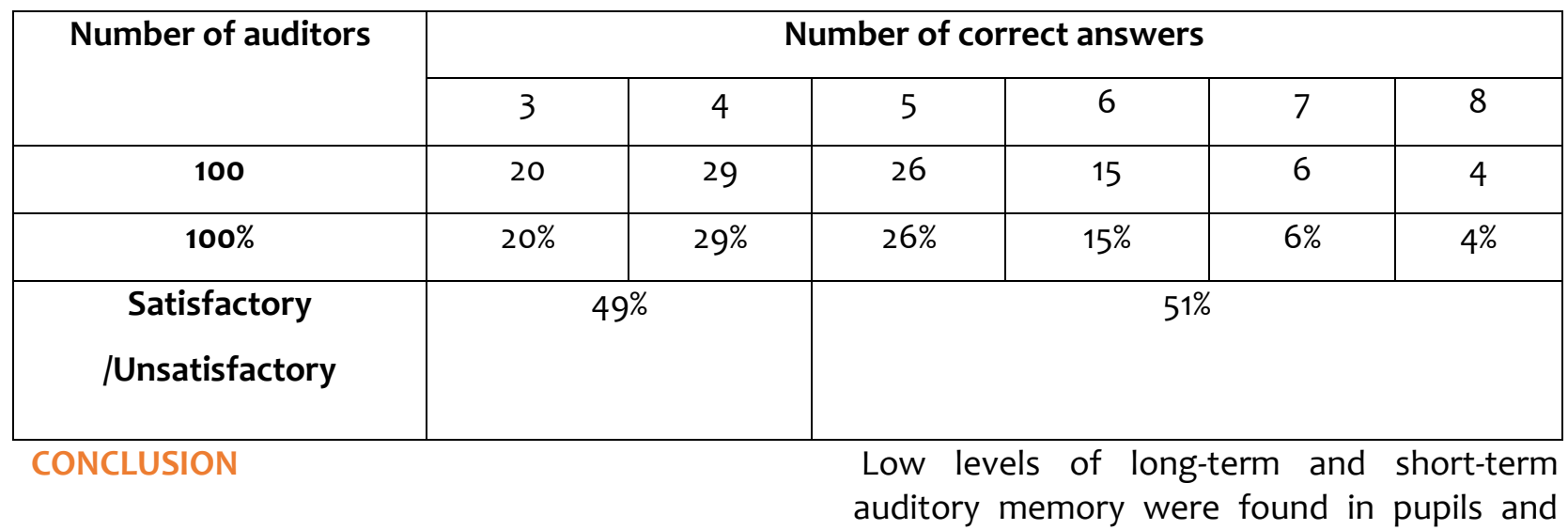


students. We believe that the main reasons for this are the lack of a healthy lifestyle among students and young people, the misuse of mobile phones, bad habits (smoking and snuff), sleep disorders, iodine deficiency and failure to perform memory exercises. possible. Decreased memory, in turn, has a negative

impact on the learning performance of students and young people.

\section{REFERENCES}

1. Guminskiy A. A., Leonteva N. N., Marinova K.V. Head to laboratory studies in general and age physiology. Moscow. Prosveshchenie, 1990. - 239 p. S. 114-116.

2. Q.Sodiqov, S.H.Aripova, G.A.Shahmurova. Age physiology and hygiene. Tashkent "Yangi asr avlodi» 2009.B.312.

3. Almatov K.T., Allamuratov Sh.I. Human and animal physiology. University. Tashkent. 2004.

4. Vlasova A., Vedenina O.A. Influence of the regime of the day on health and success obuchayushchixsya. "Rossiyskiy gosudarstvennyy professionalnopedagogicheskiy universitet», g. Ekaterinburg, Russia. S.7374.

5. Vershinin A. E., Avdonina L. A .. Influence of cell phones on the health of man. Bulletin of the Penza State University №3 (11), 2015. S. 175-176.

6. Shavazi R. N., Shamsiev Sh. J. Physiology pamyati: the role of technogenic factor. Current problems of the basic sciences of physiology and valeology. Proceedings of the Republican online scientific conference Namangan. 2020, June 19-20.S. 50-54.

7. Sayfiddin Fakhriddin oglu, Kadyrjin Roziyev. The path to happiness in both worlds. Basics of valeology. Tashkent. 2007. -B. 246
8. Troshina E.A., Soloveva S.I., Platonova N.M. and dr. Intellectual development of schoolchildren with diffuse clinical euthyroidism in the region with different iodine obesity. Pediatric Pharmacology, 2009, 6 (2): C. 43-48.

9. Saidov S.A., Saydaliyeva F.A., Yusupova D.A., Shiltsova N.V., Sultanova R.X. Educational-methodical complex "Pharmaceutical care". Tashkent. 2016. B. 183

10. shcheplyagina L. A., Makulova N. D., Maslova O. I. Iodine and intellectual development of the child // Russian medical journal. - 2002. - № 10 (7). - S. 358363.

11. E.Nuritdinov. Human Physiology (Textbook). Tashkent «Aloqachl» 2005.-B. 508.

12. B. To'raev, M. Mamajanov. The amount of long-term and short-term auditory memory in students and the factors affecting them. NamSU "Scientific journal of gifted students" No. 1, 2019. B. 22-29.

13. (m.crimea.ria.ru)

14. (studref.com)

15. (otherreferats.allbest.ru) 